\author{
@() (1) \\ Jurnal Pendidikan Dasar Indonesia is licensed under \\ A Creative Commons Attribution-Non Commercial 4.0 International License
}

\title{
PENGARUH MODEL PEMBELAJARAN PROBLEM BASED LEARNING DAN GAYA BELAJAR AUDITORIAL TERHADAP HASIL BELAJAR IPS DI SEKOLAH DASAR
}

\author{
Evinna Cinda Hendriana \\ PGSD STKIP Singkawang, Kalimantan Barat \\ Email:evinnacinda@yahoo.com
}

\begin{abstract}
Abstrak: Penelitian ini bertujuan untuk mengetahui pengaruh model pembelajaran Problem Based Learning dan gaya belajar auditorial peserta didik terhadap hasil belajar Ilmu Pengetahuan Sosial Kelas IV di Sekolah Dasar Swasta Bina Anak Muslim Singkawang. Metode penelitian ini adalah eksperimen dengan pendekatan kuantitatif. Variabel bebas (X) dalam penelitian ini adalah model pembelajaran Problem Based Learning (X1) dan gaya belajar auditorial (X2). Variabel terikat (Y) dalam penelitian ini adalah hasil belajar Ilmu Pengetahuan Sosial (Y). Populasi pada penelitian ini adalah seluruh siswa kelas IV Sekolah Dasar Swasta Bina Anak Muslim Singkawang yang berjumlah 34 orang peserta didik. Hasil penelitian menunjukkan bahwa penerapan model pembelajaran Problem Based Learning dalam pembelajaran Ilmu Pengetahuan Sosial kelas IV di Sekolah Dasar Swasta Bina Anak Muslim Singkawang memberikan pengaruh yang signifikan terhadap meningkatnya hasil belajar peserta didik dengan nilai rata-rata 82,44 . Sementara itu, gaya belajar peserta didik juga mempunyai pengaruh terhadap hasil belajar Ilmu Pengetahuan Sosial dengan nilai rata-rata 70,4. Dari hasil penelitian ini diperoleh hasil bahwa pembelajaran dengan penerapan model pembelajaran Problem Based Learning pada peserta didik dengan gaya belajar auditorial memberikan pengaruh yang kecil terhadap tingginya hasil belajar Ilmu Pengetahuan Sosial peserta didik dengan effect size sebesar 0,32 dengan kriteria besarnya effect size berada pada katagori sedang.
\end{abstract}

Kata Kunci: Model Pembelajaran PBL, Gaya Belajar Auditorial, Hasil Belajar IPS.

\section{Pendahuluan}

Pendidikan mempunyai peran penting dalam mempersiapkan sumber daya manusia yang berkualitas. Tujuan pendidikan menurut Umar Tirtarahardja dan L. La Sulo (2005:37) adalah memuat gambaran tentang nilai-nilai yang baik, luhur, pantas, benar, dan indah untuk kehidupan. Melalui pendidikan dapat diwujudkan cita-cita suatu bangsa kepada para generasi muda, khususnya bagi mereka yang masih mengenyam pendidikan formal di sekolah-sekolah. Sehubungan dengan pelaksanaan pendidikan formal di sekolah, maka dalam pelaksanaannya tidak terlepas dari adanya seseorang yang mendidik yaitu guru dan orang yang dididik yaitu peserta didik. Hubungan antara keduanya tercipta dalam beberapa hal, baik itu dalam hubungan di dalam kelas maupun hubungan di luar kelas.

Menurut Sugiyanto (2009:1) sebagai seorang pendidik, diketahui bahwa profesionalisme guru bukanlah pada kemampuannya mengembangkan ilmu pengetahuan, tetapi lebih pada kemampuannya untuk melaksanakan pembelajaran yang menarik dan bermakna bagi siswanya. Oleh sebab itu guru hendaklah membina hubungan yang baik dengan peserta didik. Hubungan di dalam kelas antara guru dan peserta didik salah satunya terlihat dalam proses pembelajaran di kelas.

Terkait dengan hubungan antara guru dan peserta didik di dalam kelas, ada beberapa permasalahan yang muncul dalam dunia pendidikan khususnya dalam proses pembelajaran di sekolah yaitu belum maksimalnya hasil belajar yang diperoleh peserta didik. Adanya program remidial yang diselenggarakan di sekolah dapat menjadi tolak ukur utama masih kurangnya hasil belajar tersebut. Namun, kita tidak dapat sepenuhnya menyalahkan peserta didik karena hasil belajarnya yang kurang baik.

Ada banyak faktor yang mempengaruhi baik buruknya hasil belajar yang diperoleh peserta didik. Sejalan dengan pendapat Daryanto dan Muljo Rahardjo (2012:212) yang menyatakan bahwa keberhasilan belajar peserta didik dipengaruhi oleh faktor internah dan eksternal. Faktor yang berasal dari dalam diri peserta didik dibagi menjadi dua yaitu faktor psikologis dan fisiologis, sedangkan faktor dari luar diri peserta didik meliputi lingkungan sekitar, guru, faktor sosial, metode pembelajaran, dll.

Guru merupakan ujung tombak pendidikan sebab guru secara langsung berupaya mempengaruhi, membina, dan mengembangkan kemampuan peserta didik agar menjadi 
manusia yang cerdas, terampil, dan bermoral tinggi. Sejalan dengan yang dikemukakan oleh Abdul Majid (2011:90) dalam kurikulum 2004 guru diberikan kebebasan untuk mengubah, memodifikasi bahkan membuat sendiri perencanaan pembelajaran yang sesuai dengan kondisi sekolah dan daerah.

Menurut Silvester Petrus Taneo, dkk (2009:8) Ilmu Pengetahuan Sosial merupakan hasil kombinasi atau hasil pemfusian atau perpaduan dari sejumlah mata pelajaran seperti geografi, ekonomi, sejarah, antropologi, dan politik. Pembelajaran Ilmu Pengetahuan Sosial ini merupakan salah satu pembelajaran pokok dan penting di Sekolah Dasar. Sesuai dengan kurikulum pendidikan nasional, bahwa setiap peserta didik harus dapat mencapai kriteria ketuntasan minimal, maka dalam memberikan pembelajaran Ilmu Pengetahuan Sosial guru harus dapat benar-benar menyampaikan bahan ajar kepada peserta didik secara efektif dan dapat dipahami oleh peserta didik.

Faktor lain yang menentukan meningkatnya hasil belajar siswa yaitu pemilihan model pembelajaran yang tepat akan mempengaruhi suasana belajar yang menyenangkan dan memungkinkan peserta didik untuk mengembangkan kreatifitas. Seperti yang diungkapkan oleh Djamarah (2006:158) bahwa penggunaan model pembelajaran yang bervariasi dapat menggairahkan belajar anak didik, pada suatu kondisi tertentu seorang anak akan merasa bosan dengan model pembelajaran ceramah maka guru perlu mengalihkan suasana dengan menggunakan model pembelajaran lain seperti tanya jawab, diskusi atau penugasan sehingga kebosanan dapat terobati dan suasana kegiatan pengajaran jauh dari kelesuan. Sama halnya dengan pembelajaran Ilmu Pengetahuan Sosial, mengingat cakupan materi Ilmu Pengetahuan Sosial yang cukup luas seorang guru Ilmu Pengetahuan Sosial harus mampu menentukan model pembelajaran yang tepat dan bervariasi agar tujuan pembelajaran dapat terpenuhi serta pembelajaran tidak terkesan membosankan.

Salah satu model pembelajaran yang melibatkan interaksi peserta didik yaitu model pembelajaran Problem Based Learning (PBL). Sugiyanto (2010:159) mengemukakan bahwa model pembelajaran Problem Based Learning ini lebih menekankan pada aktivitas peserta didik dalam mencari solusi ketika menghadapi suatu permasalahan. Peserta didik dibagi menjadi beberapa kelompok dan dihadapkan pada suatu masalah yang sama untuk dicari penyelesaiannya disetiap kelompok. Dalam penerapan model pembelajaran ini, guru memberikan kesempatan kepada peserta didik untuk menentukan topik masalah, walaupun sebenarnya guru sudah mempersiapkan apa yang harus dibahas. Proses pembelajaran diarahkan agar peserta didik mampu menyelesaikan masalah secara sistematis dan logis.

Problem Based Learning merupakan pembelajaran yang berdasarkan pada masalah-masalah kontekstual, yang membutuhkan upaya penyelidikan dalam usaha memecahkan masalah. Model pembelajaran berbasis masalah meliputi pengajuan pertanyaan atau masalah, memusatkan pada keterkaitan antardisiplin, penyelidikan autentik, kerja sama dan menghasilkan karya serta penghargaan (Hosnan,
2014:295).

Menurut Arends (2007:42) mengenai esensi Problem Based Learning berupa menyugguhkan berbagai situasi bermasalah yang autentik dan bermakna kepada siswa, yang berfungsi untuk bahan investigasi dan penyelidikan bagi siswa. Tugas siswa adalah berusaha dalam menyelidiki dan memecahkan masalah yang disugguhkan dalam proses pembelajaran.

Pendapat lain disampaikan oleh McConnell, D (2002:62) yang mengatakan bahwa Problem-based learning is carried out through an action research mode of learning, and is based on a philosophy wich acknowladges that people learn in different ways. The action learning/ research focus allows participants to make choices about the management, focus and direction of their learning.

Menurut Made Wena (2011:91) pembelajaran berbasis masalah merupakan pembelajaran dengan menghadapkan siswa pada permasalahan-permasalahan praktis sebagai pijakan dalam belajar. Senada dengan hal tersebut menurut Bound, Fellateti dan Fograty (Made Wena, 2011:91) pembelajaran berbasis masalah merupakan suatu pembelajaran dengan membuat konfrontasi kepada siswa dengan masalah-masalah praktis, berbentuk open ended melalui stimulus dalam belajar.

Faktor lain yang perlu diperhatikan dari seorang siswa yaitu faktor yang berasal dari diri siswa (internal), salah satu faktor internal tersebut yang cukup mempengaruhi hasil belajar peserta didik yaitu gaya belajar. Setiap peserta didik mempunyai cara sendiri-sendiri dalam menyerap pembelajaran yang disampaikan oleh guru. Menurut Carol Ann Tomlinson, dkk (2003:129) "The term learning profile refers to students preferred mode of learning that can be affected by a numbr of factor including learning style”. Guru perlu memerhatikan perbedaan yang ada pada peserta didik, hal ini merupakan salah satu cara guru dalam mendekatkan diri pada peserta didik.

Karakteristik peserta didik yang berbeda-beda tersebut menjadikan adanya perbedaan peserta didik dalam memahami setiap materi yang disampaikan guru. Oleh karena itu, guru mempunyai tugas yang lebih berat karena guru harus mengetahui karakteristik setiap peserta didik, dengan cara demikian akan memudahkan guru untuk melaksanakan kegiatan pembelajaran di kelas.

Uno (2006:181) mengatakan bahwa gaya belajar pada diri peserta didik secara garis besar ada 3, yaitu gaya belajar Visual, Auditory, dan Kinestetik. Ketiga tipe gaya belajar pada diri peserta didik ini mempunyai cara dan pendekatan yang berbeda-beda sesuai dengan karakteristik yang dimiliki oleh peserta didik. Sama halnya pada pembelajaran Ilmu Pengetahuan Sosial, tipe gaya belajar peserta didik tentunya juga berbeda-beda sesuai kemampuan peserta didik dalam mengolah materi Ilmu Pengetahuan Sosial yang cukup banyak dan luas.

DePorter \& Hernacki (2002: 110) mengemukakan bahwa gaya belajar seseorang adalah kombinasi dari bagaimana ia menyerap dan kemudian mengatur serta mengolah informasi. Selanjutnya Junierissa Marpaung (2015:82) berpendapat 
bahwa gaya belajar adalah cara manusia mulai berkonsentrasi, menyerap, memproses dan mnampung informasi yang bar dan sulit.

Heinich (1996:37) mengatakan bahwa :'Learning style refers to a cluster of psychological traits that determine how an individual perceives, interacts with, and responds emotionally to learning enviroments". Gaya belajar atau kebiasaan belajar bertujuan untuk mengelompokkan psikologi dalam menentukan bagaimana seorang individu atau peserta didik melihat, berinteraksi, dan merespon perasaannya dalam lingkungan belajar.

Gaya belajar adalah cara yang paling disukai, paling dominan dalam proses belajarnya, di mana individu dapat menerima, menyerap, mengatur, dan mengolah informasi yang ia dapatkan. Seorang guru atau pendidik seharusnya memang memperhatikan perbedaan gaya belajar pada peserta didik. Hal ini bertujuan untuk mempermudah guru dalam menentukan model pembelajaran yang tepat diberikan untuk siswa, sehingga materi pembelajaran akan lebih mudah diterima.

Dari pemaparan di atas dapat disimpulkan bahwa gaya belajar sangat penting ketika seseorang tinggal di suatu tempat. Ketika peserta didik sudah mengetahui gaya belajarnya maka akan mempermudah peserta didik tersebut mengikuti kegiatan pembelajaran, sehingga peserta didik akan lebih mudah belajar dan lebih cepat untuk sukses dalam menerima proses pembelajaran.

Keuntungan lain yang didapatkan dari mengidentifikasi gaya belajar peserta didik yaitu peserta didik akan lebih mudah dan efektif dalam menyelesaikan suatu permasalahan yang dihadapkan. Ketika seorang peserta didik sudah mampu menyelesaikan masalah yang dihadapi maka akan membuat peserta didik lebih mengendalikan dirinya dalam kebiasaan hidupnya.

Ada beberapa tipe gaya belajar yang dimiliki oleh peserta didik. Hal ini sesuai dengan karakteristik peserta didik yang berbeda satu dengan yang lainnya. DePorter \& Hernacki (2002: 116) mengatakan bahwa gaya belajar dapat digolongkan menjadi tiga yaitu gaya belajar visual, gaya belajar auditorial, dan gaya belajar kinestetik. 1) gaya belajar visual menjelaskan bahwa seseorang gaya belajar ini harus melihat dahulu bukti-bukti untuk kemudian dapat mempercayainya, contohnya melalui ilustrasi gambar, video, dan lain-lain; 2) Selanjutnya gaya belajar auditorial merupakan gaya belajar yang mengandalkan pada pendengaran untuk dapat memahami dan mempercayainya; 3) gaya belajar kinestetik merupakan gaya belajar dimana seseorang tersebut memanfaatkan bagian-bagian tertentu dari fisiknya sebagai alat belajar yang optimal dapat digolongkan seseorang tersebut memiliki gaya belajar kinestetik.

Hamzah B. Uno (2006:181) mengungkapkan bahwa gaya belajar auditorial mengandalkan pada pendengaran untuk bisa memahami dan memproses informasi atau pengetahuan dalam suatu proses pembelajaran.

Ciri-ciri gaya belajar sebagai penanda gaya belajar mana yang lebih dominan bagi seseorang. Ciri-ciri gaya belajar menurut DePorter \& Hernacki (2009:116) antara lain karakteristik bagi siswa yang mempunyai gaya belajar visual antara lain: siswa cenderung rapi dan teratur, berbicara dengan cepat,perencana dan pengatur jangka panjang yang baik, teliti dan detail dan setiap urusan yang ditanganinya, lebih mementingkan penampilan karena pada karakteristik siswa pada gaya belajar ini cenderung lebih menggunakan indera penglihatannya sehingga jika merasa penampilannya sudah baik maka akan lebih percaya diri (baik dalam hal pakaian maupun presentasi), pengeja yang baik dan dapat melihat kata-kata yang sebenarnya dalam pikiran mereka, mengingat apa yang dilihat dari pada apa yang didengar dengan cara asosiasi visual, dan tidak mudah terganggu konsentrasinya apabila ada keributan.

Kesesuaian antara model pembelajaran Problem Based Learning dan gaya belajar auditorial berpengaruh terhadap hasil belajar Ilmu Pengetahuan Sosial. Hasil belajar adalah tingkat penguasaan yang telah dicapai oleh peserta didik setelah mengikuti pelajaran dengan tujuan yang telah diterapkan. Ang Chen dan Bo Shen (2004:4) menyatakan bahwa "The students achievement goal orientions were measured using the 13-item (five point scale) task and ego persentation in sport questionnaire". Sementara itu menurut Hadari Nawawi (2007:240), "Hasil belajar atau prestasi belajar merupakan tingkat kepandaian peserta didik dalam mempelajari materi pelajaran yang diperoleh dari hasil tes mengenai sejumlah materi pelajaran tertentu".

Dimyati dan Mudjiono (2015:201) mengemukakan bahwa hasil belajar merupakan pencapaian bentuk perubahan perilaku yang cenderung menetap dari ranah kognitif, afektif, dan psikomotoris dari proses belajar yang dilakukan dalam waktu tertentu.

Subramaniam (2009:11) "Achievement goals have been reported to have a weak influence in predicting both performance and motivation outcome". Sejalan dengan itu, Sri Anitah W, dkk (2008:2.19) menyatakan bahwa "Hasil belajar merupakan kulminasi dari suatu proses yang telah dilakukan dalam belajar. Hasil belajar harus menunjukkan suatu perubahan tingkah laku atau perolehan tingkah laku yang baru dari siswa yang besifat permanen, fungsional, positif, dan disadari.

Berkaitan dengan pembelajaran Ilmu Pengetahuan Sosial yang membutuhkan pemahaman materi yang cukup luas dan umumnya dikenal cukup sulit bagi peserta didik, maka diperlukan pemahaman tentang pemilihan model pembelajaran yang tepat dan sesuai dengan tipe gaya belajar peserta didik.

Penelitian oleh Tanta (2010:9) menunjukkan bahwa pembelajaran di dalam kelas lebih didominasi oleh siswa yang memiliki gaya belajar visual sebesar 49,92\%. Sejalan dengan itu penelitian lain juga dilakukan oleh Tuti Mutia (2015:109) didapatkan hasil bahwa model pembelajaran Problem Based Learning cocok diterapkan pada peserta didik yang memiliki kecenderungan gaya belajar visual dan dapat mempengaruhi hasil belajar peserta didik sebesar 79,88\%. 


\section{Metode Penelitian}

Rancangan penelitian ini mengunakan pendekatan kuantitatif dengan metode penelitian eksperimen. Penelitian ini merupakan penelitian jenis Pre-Experimental design (nondesign). Paradigma penelitian pengaruh model pembelajaran Problem Based Learning dan gaya belajar visual terhadap hasil belajar Ilmu Pengetahuan Sosial peserta didik Sekolah Dasar, divisualisasikan pada bagan berikut.

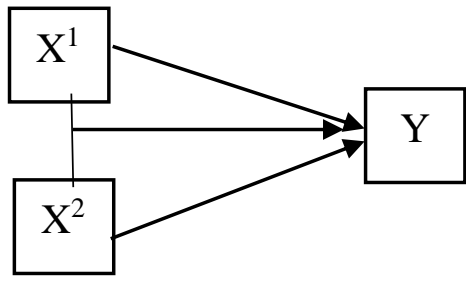

Bagan 1

Hubungan Antar Variabel

$\mathrm{X} 1$ = Model pembelajaran PBL

$\mathrm{X} 2$ = Gaya belajar visual

$\mathrm{Y}=$ Hasil belajar IPS

Penelitian ini menggunakan teknik tes dan non tes. Alat pengumpul data dalam penelitian ini adalah soal tes dan angket gaya belajar. Soal tes disusun oleh peneliti dalam bentuk tes objektif (pilihan ganda) dengan 4 pilihan jawaban sejumlah butir soal. Perhitungan hasil belajar peserta didik ini yang akan digunakan sebagai penentuan perbedaan hasil belajar peserta didik yang dipengaruhi oleh penerapan metode Problem Based Learning yang dikontrol oleh gaya belajar visual. Angket yang digunakan dalam penelitian adalah angket langsung. Bentuk lembaran angket berupa sejumlah pertanyaan tertulis, tujuannya untuk memperoleh informasi dari responden tentang apa yang ia alami dan ketahui.

Analisis data dilakukan dengan pengujian hipotesis berbantuan program SPSS 16.

\section{HASIL DAN PEMBAHASAN}

\section{Hasil}

Berdasarkan perhitungan menggunakan program SPSS 16. Skor jawaban angket dari 34 responden pada diperoleh penyebaran skor sebagai berikut.

Tabel 1

Analisis Perolehan Skor Angket Gaya Belajar

\begin{tabular}{|c|c|c|c|}
\hline \multicolumn{3}{|c|}{ Kategori Gaya Belajar } & \multirow{2}{*}{$\begin{array}{l}\text { Jumlah } \\
\text { Siswa }\end{array}$} \\
\hline Visual & Auditorial & Kinestetik & \\
\hline 25 & 5 & 4 & 34 \\
\hline
\end{tabular}

Dari tabel 1 dapat diketahui bahwa dalam kelas eksperimen model pembelajaran Problem Based Learning terdapat peserta didik dengan gaya belajar visual yang berjumlah 25 orang, gaya belajar auditorial yang berjumlah 5 , dan gaya belajar kinestetik yang berjumlah 4 orang dari jumlah keseluruhan siswa dalam satu kelas 34 orang.

Pengelompokkan gaya belajar didapatkan dari membandingkan jumlah skor angket gaya belajar dimana kelompok visual terdiri dari 9 pernyataan, kelompok auditorial 9 pernyataan, dan kelompok kinestetik 9 pernyataan. Jumlah skor dari tiga gaya belajar itu kemudian dibandingkan. Jika siswa memiliki jumlah skor yang lebih dominan diantara tiga gaya belajar itu maka siswa tersebut mempunyai kecenderungan gaya belajar yang dominan apakah gaya belajar visual, gaya belajar auditorial, atau gaya belajar kinestetik. Fokus dalam penelitian ini yaitu peserta didik dengan gaya belajar visual yang berjumlah 25 orang peserta didik.

Tabel 2

Rangkuman Perbandingan Hasil Analisis Deskriptif Pretest dan Posttest dengan Gaya Belajar Auditorial

\begin{tabular}{lll}
\hline Besaran Statistik & Pretest & Posttest \\
\hline Mean & 68,5 & 70,4 \\
\hline Standar Deviasi & 5,528 & 5,352 \\
\hline Skor Minimum & 60 & 64 \\
\hline Skor Maksimum & 76 & 72 \\
\hline
\end{tabular}

Berdasarkan hasil pretest kelas eksperimen Problem Based Learning dalam pembelajaran IPS didapatkan skor terendah 52, skor tertinggi 76 , nilai rata-rata sebesar 65,058 dan standar deviasi sebesar 5,683. Sementara itu, hasil posttest kelas eksperimen Problem Based Learning dalam pembelajaran IPS didapatkan skor terendah 64, skor tertinggi 92, nilai rata-rata sebesar 82,44 dan standar deviasi sebesar 5,352 .

Berdasarkan hasil pretest kelas eksperimen model pembelajaran Problem Based Learning pada peserta didik dengan gaya belajar auditorial didapatkan skor terendah 60 , skor tertinggi 76 , nilai rata-rata sebesar 68,5 dan standar deviasi sebesar 5,528. Sementara itu, hasil posttest kelas eksperimen model pembelajaran Problem Based Learning pada peserta didik dengan gaya belajar auditorial didapatkan skor terendah sebesar 64 , skor tertinggi 72 , nilai rata-rata sebesar 70,4 dan standar deviasi sebesar 5,352.

Berdasarkan rangkuman hasil analisis statistik deskriptif diketahui bahwa terdapat perbedaan perolehan skor antara pretest dan posttest peserta didik dengan penerapan model Problem Based Learning kategori gaya belajar auditorial. Hal itu ditunjukkan dengan skor minimum dan skor maximum pada posttest Problem Based Learning kategori gaya belajar auditorial yang tidak lebih tinggi. Pada kelompok eksperimen kategori gaya belajar auditorial, yang 
dalam pembelajaran menggunakan model Problem Based Learning skor minimum adalah 64 dan skor maximum 72.

Tabel 3

Hasil Effect Size

\begin{tabular}{lll}
\hline Keterangan & Pretest & Posttest \\
\hline Rata-rata & $\mathbf{6 8 , 5}$ & $\mathbf{7 0 , 4}$ \\
\hline
\end{tabular}

Simpangan Baku

ES

$\mathbf{0 , 3 2}$

Untuk mengetahui hasil belajar siswa dikatakan terdapat pengaruh dalam penerapan model pembelajaran Problem Based Learning pada peserta didik dengan gaya belajar visual maka dilakukan perhitungan besarnya efek dari perlakuan tersebut (effect size) dan diperoleh efek dari perlakuan tersebut adalah 0,32 dengan kriteria besarnya effect size berada pada katagori sedang yaitu pada rentang ES >0,8.

Tabel 4

Ringkasan Uji Hipotesis

\begin{tabular}{lll}
\hline Kategori & Skor Rerata & Nilai Sig \\
\hline $\begin{array}{l}\text { Model Problem Based } \\
\text { Learning }\end{array}$ & 82,44 & 0,000 \\
\hline Gaya Belajar Visual & 83,68 & 0,000 \\
\hline Gaya Belajar Auditorial & 70,40 & 0,178 \\
\hline Gaya Belajar Kinestetik & 67 & 0,172 \\
\hline
\end{tabular}

\section{Hasil Hipotesis Pertama}

Berdasarkan tabel 4 dapat diketahui bahwa perhitungan tentang penerapan model pembelajaran Problem Based Learning terhadap hasil belajar Ilmu Pengetahuan Sosial menunjukkan peluang kesalahan atau probabilitas sebesar $0,000<0,05$.

Berdasarkan hal tersebut dapat ditarik kesimpulan bahwa Ho ditolak dan Ha diterima. Pada rerata hasil belajar Ilmu Pengetahuan Sosial pada kelas eksperimen menunjukkan bahwa hasil belajar siswa dengan menerapkan model pembelajaran Problem Based Learning lebih tinggi. Rerata hasil belajar dengan menerapkan model pembelajaran Problem Based Learning sebesar 82,44. Artinya bahwa penerapan model pembelajaran Problem Based Learning berpengaruh secara signifikan terhadap hasil belajar Ilmu Pengetahuan Sosial. Dengan demikian hipotesis pertama yang menyebutkan bahwa: Terdapat pengaruh penerapan model pembelajaran Problem Based Learning terhadap hasil belajar Ilmu Pengetahuan Sosial di Sekolah Dasar. Hasil belajar siswa dengan menggunakan model pembelajaran Problem
Based Learning lebih tinggi sehingga hipotesis dinyatakan diterima.

\section{Hasil Hipotesis Kedua}

Berdasarkan tabel 4 dapat diketahui bahwa perhitungan tentang gaya belajar auditorial peserta didik dalam pembelajaran Ilmu Pengetahuan Sosial menunjukkan peluang kesalahan atau probabilitas sebesar $0,000<\alpha=0,05$. Berdasarkan hal tersebut dapat disimpulkan bahwa Ho ditolak dan Ha diterima. Berarti bahwa terdapat pengaruh pengelompokkan gaya belajar auditorial terhadap hasil belajar Ilmu Pengetahuan Sosial menunjukkan bahwa hasil belajar peserta didik yang memiliki gaya belajar auditorial tidak begitu meningkat. Rerata peserta didik yang memiliki gaya belajar auditorial dalam pembelajaran Ilmu pengetahuan Sosial sebesar 70,4. Artinya bahwa pengelompokkan gaya belajar peserta didik berpengaruh secara signifikan terhadap hasil belajar Ilmu Pengetahuan Sosial. Dengan demikian hipotesis kedua yang menyebutkan bahwa: Terdapat pengaruh gaya belajar auditorial peserta didik dalam pembelajaran terhadap hasil belajar Ilmu Pengetahuan Sosial di Sekolah Dasar.

\section{Hasil Hipotesis Ketiga}

Berdasarkan tabel 4 dapat diketahui bahwa penerapan model pembelajaran Problem Based Learning pada peserta didik dengan gaya belajar auditorial mempengaruhi hasil belajar lmu Pengetahuan Sosial menunjukkan peluang kesalahan atau probabilitas sebesar $0,000>\alpha=0,05$. Sehingga Ha ditolak dan Ho diterima. Hal ini memiliki pengertian bahwa terdapat pengaruh yang kurang signifikan antara model pembelajaran Problem Based Learning dan gaya belajar auditorial dalam memengaruhi hasil belajar. Dengan demikian dapat disimpulkan bahwa hipotesis ke tiga yang menyebutkan bahwa: Terdapat pengaruh model pembelajaran Problem Based Learning dan gaya belajar auditorial secara bersama-sama terhadap hasil belajar Ilmu Pengetahuan Sosial Kelas IV di Sekolah Dasar Swasta Bina Anak Muslim Singkawang. Hasil belajar peserta didik dengan penerapan model pembelajaran Problem Based Learning pada gaya belajar auditori tidak begitu tinggi sehingga hipotesis dinyatakan diterima.

Pengaruh model pembelajaran Problem Based Learning dan gaya belajar auditorial dalam memengaruhi hasil belajar Ilmu Pengetahuan Sosial dengan ES 0,32 sehingga dapat dinyatakan bahwa penerapan model pembelajaran Problem Based Learning pada siswa dengan gaya belajar auditorial memiliki pengaruh yang kurang signifikan terhadap hasil belajar Ilmu Pengetahuan Sosial dengan kategori sedang.

\section{PEMBAHASAN}

Pengaruh Model Pembelajaran Problem Based Learning terhadap Hasil Belajar IPS

Hipotesis pertama yang telah diuji menyatakan terdapat pengaruh model pembelajaran Problem Based Learning terhadap hasil belajar Ilmu Pengetahuan Sosial 
Kelas IV di Sekolah Dasar Swasta Bina Anak Muslim Singkawang.

Salah satu permasalahan yang muncul dalam dunia pendidikan khususnya yang berkaitan dalam proses pembelajaran di sekolah adalah belum maksimalnya hasil belajar siswa. Ada beberapa faktor yang mempengaruhi baik buruknya hasil belajar siswa tersebut, faktor tersebut dapat berasal dari dalam diri siswa maupun dari luar diri siswa. Pemilihan metode pembelajaran yang tepat akan mempengaruhi suasana belajar yang menyenangkan dan memungkinkan siswa mengembangkan kreativitas.

Berbeda dengan kenyataan yang ada di lapangan bahwa belum semua pembelajaran Ilmu Pengetahuan Sosial dilakukan dengan model pembelajaran yang menarik dan bervariasi. Teknik mengajar guru yang masih banyak didominasi metode ceramah membuat siswa kurang terstimulasi untuk mengembangkan pengetahuannya.

Pada hasil penelitian di kelas IV Sekolah Dasar Bina Anak Muslim Singkawang dengan menerapkan model pembelajaran Problem Based Learning menunjukkan hasil yang signifikan. Hal ini sesuai dengan dengan hasil analisis data pada hipotesis pertama, hasil analisis menunjukkan bahwa rerata hasil belajar dengan menggunakan model Problem Based Learning meningkat. Hasil analisis data menunjukkan bahwa pengaruh metode pembelajaran terhadap hasil belajar Ilmu Pengetahuan Sosial menunjukkan peluang kesalahan atau probabilitas sebesar $0,000<$ nilai $\alpha=0,05$ yang berarti bahwa terdapat pengaruh yang signifikan antara model pembelajaran Problem Based Learning terhadap hasil belajar Ilmu Pengetahuan Sosial di Sekolah Dasar. Terlihat jelas pada hasil belajar siswa (posttest) dengan menggunakan model pembelajaran Problem Based Learning sebesar 82,44 lebih tinggi daripada rerata nilai pretest sebesar 65,05.

Dengan demikian terdapat pengaruh model pembelajaran Problem Based Learning terhadap hasil belajar Ilmu Pengetahuan Sosial di Sekolah Dasar. Hasil belajar siswa dengan menggunakan model pembelajaran Problem Based Learning lebih tinggi.

\section{Pengaruh Gaya Belajar Auditorial terhadap Hasil Belajar IPS}

Hipotesis kedua yang telah diuji menyatakan terdapat pengaruh gaya belajar auditorial peserta didik dalam pembelajaran terhadap hasil belajar Ilmu Pengetahuan Sosial Kelas IV di Sekolah Dasar Swasta Bina Anak Muslim Singkawang.

Setiap Peserta didik memiliki ciri masing-masing dalam menentukan bagaimana cara belajar yang disukai kemudian diterapkan, hal inilah yang sering disebut dengan gaya belajar siswa. Gaya belajar ini sangat dipengaruhi oleh faktor kebiasaan siswa dalam berinteraksi dengan lingkungannya termasuk guru dalam mengajar di kelas. Pemahaman tersebut dijadikan salah satu pedoman untuk mengetahui kecenderungan gaya belajar siswa yang cocok apakah visual, auditorial maupun kinestetik. Permasalahannya adalah bagaimana guru dapat mengolah potensi siswa dengan gaya belajar yang sedemikian rupa agar siswa itu dapat termotivasi untuk menyukai pembelajaran Ilmu Pengetahuan Sosial.

Peserta didik dengan gaya belajar visual cenderung harus melihat dulu buktinya untuk kemudian mempercayainya sehingga mereka dapat memahami apa yang sedang mereka pelajari dengan melihat. Peserta didik dengan gaya belajar visual akan memiliki interes yang tinggi ketika diperlihatkan gambar, grafik, grafis dan ilustrasi visual lainnya (Kurniawan \& Riyana, 2011: 33-35).

Berbeda halnya dengan Peserta didik gaya belajar auditorial, menurut Uno (2006: 181-182) pada gaya belajar ini memanfaatkan kemampuan pendengarannya sebagai cara belajar yang disukainya. Gaya belajar auditorial merupakan gaya belajar dimana peserta didik belajar melalui mendengarkan. Peserta didik dengan tipe gaya belajar ini akan dapat menghafal dengan cepat melalui membaca teks dengan keras atau mendengarkan media audio. Sedangkan pada peserta didik dengan gaya belajar kinestetik, lebih banyak belajar melalui bergerak, menyentuh, dan melakukan. Peserta didik seperti ini sulit duduk berjam-jam.

Secara teori penerapan model pembelajaran Problem Based Learning yang menampilkan permasalahan secara nyata dalam bentuk visual dan dengan apersepsi melalui tampilan gambar atau video memang lebih cocok diterapkan pada siswa dengan gaya belajar visual. Hal ini dapat dikatakan penulis demikian karena peserta didik dengan tipe gaya belajar visual lebih banyak menggunakan indera penglihatannya untuk memahami sesuatu. peserta didik dengan tipe gaya belajar visual akan memiliki interes yang tinggi ketika diperlihatkan gambar atau ilustrasi visual lainnya.

Berdasarkan penelitian yang telah dilakukan, gambaran di atas ternyata cocok dengan pembuktian pada hasil analisis hipotesis kedua yang menunjukkan bahwa rerata hasil hasil belajar siswa dengan penerapan model pembelajaran Problem Based Learning lebih tinggi pada gaya kelompok siswa gaya belajar auditorial. Hal itu ditunjukkan pada hasil uji hipotesis 2 yang menyebutkan bahwa pengaruh gaya belajar terhadap hasil belajar IPS menunjukkan peluang kesalahan atau probabilitas sebesar $0,000<\alpha=0,05$. Berdasarkan hal tersebut dapat disimpulkan bahwa Ho ditolak dan Ha diterima. Berarti bahwa terdapat pengaruh antara gaya belajar terhadap hasil belajar IPS. Berdasarkan tabel 4 dapat dilihat bahwa hasil rerata kelas eksperimen menunjukkan bahwa hasil belajar siswa dengan menggunakan model pembelajaran Problem Based Learning lebih tinngi pada kategori gaya belajar auditorial. Hal itu dapat terlihat pada hasil rerata model pembelajaran Problem Based Learning dengan gaya belajar auditorial sebesar 68,8 lebih tinngi daripada hasil rerata total hasil pretest sebesar 70,4.

Pengaruh Model Pembelajaran Problem Based Learning dan Gaya Belajar Auditorial secara bersama-sama terhadap Hasil Belajar IPS

Hipotesis ketiga yang telah diuji menyatakan terdapat pengaruh model pembelajaran Problem Based Learning dan gaya belajar auditorial secara bersama-sama terhadap hasil 
belajar Ilmu Pengetahuan Sosial Kelas IV di Sekolah Dasar Swasta Bina Anak Muslim Singkawang.

Pelaksanaan kasil eksperimen yang dilakukan di Sekolah Dasar Swasta Bina Anak Muslim Singkawang dengan menerapkan model pembelajaran Problem Based Learning ini merupakan salah satu terobosan dalam pembelajaran, khususnya pada mata pelajaran Ilmu Pengetahuan Sosial. Penerapan model pembelajaran Problem Based Learning baik untuk meningkatkan hasil belajar peserta didik apabila diterapkanpada peserta didik dengan gaya belajar visual sehingga akan berdampak positif. Berdasarkan hasil penelitian di Sekolah Dasar Swasta Bina Anak Muslim Singkawang yang digunakan sebagai sampel penelitian, ternyata hasilnya menunjukkan taraf yang signifikan.

Hasil belajar peserta didik pada dasarnya dipengaruhi oleh dua faktor, yaitu faktor yang berasal dari dalam diri peserta didik dan faktor yang berasal dari luar diri siswa. Faktor yang berasal dari dalam meliputi faktor psikologis dan fisiologis, sedangkan faktor dari luar meliputi lingkungan sekitar, guru, mata pelajaran, metode pembelajaran, dll (Ngalim Purwanto, 2006: 106-107). Peserta didik tidak dianggap sebagai objek yang tidak tahu apa-apa, namun kebalikannya peserta didik justru dianggap sebagai subjek yang memiliki latar belakang, minat, gaya belajar, kebutuhan serta kemampuan yang berbeda. Guru hendaknya mampu memahami perbedaan individu dalam hal ini gaya belajar sebagai komponen yang saling mempengaruhi terhadap hasil belajar yang diperoleh peserta didik.

Gambaran di atas ternyata sesuai dengan hasil hipotesis yang diperoleh dalam penelitian. Hasil hipotesis menunjukkan bahwa penerapan model pembelajaran Problem Based Learning pada peserta didik dengan gaya belajar visual mempengaruhi hasil belajar Ilmu Pengetahuan Sosial yang menunjukkan peluang kesalahan atau probabilitas sebesar $0,000<\alpha=0,05$. Hal ini menunjukkan bahwa Ha diterima dan Ho ditolak. Artinya bahwa terdapat pengaruh signifikan antara model pembelajaran Problem Based Learning dan gaya belajar visual dalam mempengaruhi hasil belajar Ilmu Pengetahuan Sosial.

\section{KESIMPULAN DAN SARAN}

Berdasarkan analisis dan pembahasan hasil penelitian dapat disimpulkan bahwa: (1) Terdapat pengaruh penerapan model pembelajaran Problem Based Learning terhadap hasil belajar Ilmu Pengetahuan Sosial dengan perolehan rata-rata 82,44 , sehingga dapat dinyatakan bahwa penerapan model pembelajaran Problem Based Learning berpengaruh terhadap meningkatnya hasil belajar peserta didik dalam pembelajaran Ilmu Pengetahuan di Kelas IV Sekolah Dasar Swasta Bina Anak Muslim Singkawang. (2) Terdapat pengaruh gaya belajar auditorial peserta didik terhadap hasil belajar Ilmu Pengetahuan Sosial dengan perolehan rata-rata 70,4, sehingga dapat dinyatakan bahwa penggolongan gaya belajar auditorial berpengaruh terhadap meningkatnya hasil belajar peserta didik dalam pembelajaran Ilmu Pengetahuan di Kelas IV Sekolah Dasar Swasta Bina Anak Muslim Singkawang. (3)
Pembelajaran dengan penerapan model pembelajaran Problem Based Learning pada peserta didik dengan gaya belajar visual memberikan pengaruh yang besar terhadap tingginya hasil belajar Ilmu Pengetahuan Sosial peserta didik dengan effect size sebesar 3,55 dengan kriteria besarnya effect size berada pada katagori tinggi yaitu pada rentang ES > 3,55.

\section{SARAN}

Berdasarkan hasil pengujian menunjukkan bahwa terdapat pengaruh yang positif dan signifikan terhadap pengaruh penerapan model pembelajaran Problem Based Learning dan gaya belajar auditorial terhadap hasil belajar Ilmu Pengetahuan Sosial di kelas IV Sekolah Dasar Swasta Bina Anak Muslim Singkawang.

Saran pada penelitian ini ialah; (1) Dalam melaksanakan pembelajaran Ilmu Pengetahuan Sosial guru hendaknya lebih menerapkan model pembelajaran yang bervariasi dan lebih mempertimbangkan gaya belajar peserta didik agar peserta didik lebih tertarik untuk mengikuti pembelajaran, sehingga berdampak pada peningkatan hasil belajar Ilmu Pengetahuan Sosial. (2) Model pembelajaran Problem Based Learning terbukti dapat meningkatkan hasil belajar Ilmu Pengetahuan Sosial peserta didik yang memiliki gaya belajar visual secara signifikan. Oleh karena itu, hendaknya para guru mampu mengembangkan dan merancang model pembelajaran sendiri, serta harus mampu mengetahui gaya belajar peserta didik sehingga dapat digunakan sebagai penunjang dalam proses pembelajaran. (3) Untuk kesempurnaan penelitian, disarankan penelitian lanjutan agar lebih spesifik lagi karena penelitian ini kurang spesifik pada pengelompokkan gaya belajar sehingga perlu diperhatikan pada peneliti selanjutnya untuk lebih intensif pada gaya belajar sesuai dengan pengelompokkannya.

\section{DAFTAR PUSTAKA}

Abdul, M. 2009. Perencanaan Pembelajaran, Mengembangkan Standar Kompetensi Guru. Jakarta: PT. Rosda Karya.

Daryanto dan Muljo, R. 2012. Model Pembelajaran Inovatif. Yogyakarta: Gava Media.

DePorter B., \& Hernacki M. 2002. Quantum Learning. (Terjemahan Alwiyah Abdurrahman). New York: Dell Publishing.

Dimyanti dan Mudjiono. 2015. Belajar dan Pembelajaran. Jakarta: PT. Rineka Cipta.

Djamarah, S.B. \& Zein, A. (2006). Strategi Belajar Mengajar. Jakarta: Rineka Cipta.

Hadari, N. 2012. Metode Penelitian Bidang Sosial. Yogyakarta: Gadjah Mada Universitas Press.

Heinich R. 1996. Instructional Media and Technologies for Learning. New Jersey: Pretice-Hall.

Hosnan. 2014. Pendekatan Saintifik dan Kontekstual dalam Pembelajaran Abad 21. Bogor: Ghalia Indonesia. 
Junierissa, M. 2015. Pengaruh Gaya Belajar terhadap Prestsi Belajar Siswa. Jurnal KOPASTA Volume 2 No 2.

Made, W. 2011. Strategi Pembelajaran Inofatif Kontemporer. Malang: Bumi Aksara.

McConnell, D. 2002. Action research and Distributed Problem-Based-Learning in continuing profesional education. Distance Education, May 2002; 23, 1; ProQuest.

Ngalim, P. 2011. Psikologi Pendidikan. Bandung: Remaja Rosdakarya.

Rusmawan. 2013. Faktor yang Mempengaruhi Kesulitan Belajar IPS Siswa Sekolah Dasar. Cakrawala Pendidkan Jurnal Ilmiah, No. 2.

Sabramaniam. 2009. Motivational Effect of Interest on Student Engagement and Learning in Physical Eduction: A Review. Journal: Int J Phys Educ 46.

Silverter, Petrus, Taneo, dkk. 2009. Kajian IPS di SD. Jakarta: Depdiknas.

Sugiyanto. 2009. Model-model Pembelajaran Inovatif. Surakarta: Yuma Pustaka.

Tanta. 2010. Pengaruh Gaya Belajar terhadap Hasil Belajar Siswa pada Pembelajaran IPA di SDN 15 Bandung. Jurnal Kependidikan Dasar: Volume 1, Nomor 1.

Tuti, M. 2015. Pengaruh Model Pembelajaran Problem Based Learning dan Gaya Belajar terhadap Hasil Belajar IPS. Jurnal EducatiO. Volume 10, Nomor 1.

Umar, T, R dan La, S. 2005. Pengantar Pendidikan. Jakarta: Rineka Cipta. 